\title{
PERILAKU SOCIAL LOAFING DALAM PEMBELAJARAN DARING: STUDI KASUS PADA MAHASISWA PENDIDIKAN GURU SEKOLAH DASAR
}

\author{
Ishmatun Naila \\ Program Studi Pendidikan Guru Sekolah Dasar \\ ishmatun@fkip.um-surabaya.ac.id
}

\section{INFO ARTIKEL}

Riwayat Artikel:

Diterima: 29-Januari-2021

Disetujui: 30-Maret-2021

\section{Kata Kunci:}

Covid-19, Sains Sekolah Dasar, Pembelajaran Daring, Social Loafing, Calon Guru

ABSTRAK

\begin{abstract}
Abstrak: Pembelajaran daring merupakan satu-satunya cara untuk melaksanakan Pendidikan selama pandemi Covid-19. Kerja kelompok selama pembelajaran daring, dimana mahasiswa tidak dapat bertemu secara tatap muka menjadi kurang efektif dan dapat menimbulkan penurunan kinerja individu dibandingkan ketika bekerja secara mandiri, yang biasa disebut social loafing. Penelitian ini bertujuan untuk mengetahui pengaruh pembelajaran daring terhadap social loafing calon guru Sekolah Dasar. Metode yang digunakan adalah kualitatif deskriptif, dengan subjek mahasiswa Pendidikan Guru Sekolah Dasar Universitas Muhammadiyah Surabaya Angkatan 2019. Teknik analisis dilakukan dengan penyajian data setelah diolah menggunakan Microsoft Excel dan dideskripsikan secara naratif. Hasil penelitian menunjukkan bahwa terdapat indikasi calon guru terhadap social loafing dalam kerja kelompok secara daring.
\end{abstract}

\begin{abstract}
Online learning is the only way to implement education during the Covid-19 pandemic. Workgroup in online learning, where students cannot meet in real life, is less effective and can cause a decreasing performance compared to working independently, which is commonly called social loafing. This study aims to know the effect of online learning on pre-service elementary school teachers' social loafing. The method used is descriptive qualitative, with the subject Elementary School Teacher Education students or Pre-service Teachers in Muhammadiyah University of Surabaya, Class of 2019. The analysis technique was carried out by presenting the data after it was processed using Microsoft Excel and described narratively. The results showed that there are indications of pre-service teachers regarding social loafing in online group work.
\end{abstract}

\section{A. LATAR BELAKANG}

Pandemi Covid-19 mengubah semua aspek kehidupan, termasuk aktivitas pendidikan. Surat Edaran Menteri Pendidikan dan Kebudayaan Indonesia Nomor 4 Tahun 2020 tanggal 24 Maret 2020 berisi Pelaksanaan Kebijakan Pendidikan di Masa Darurat Covid-19 (Khasanah, Pramudibyanto, \& Widuroyekti, 2020). Hal tersebut menjelaskan bahwa proses pembelajaran dilakukan di rumah melalui online atau e-learning tanpa bertemu langsung dengan siswa untuk memberikan pengalaman belajar yang lebih bermakna bagi mereka. Perubahan proses pembelajaran ini bertujuan untuk mencegah penyebaran virus Covid-19. Pembelajaran online atau e-learning adalah satu-satunya cara untuk menyelenggarakan pendidikan di semua jenjang sekolah, dari sekolah dasar hingga universitas. Ada banyak sisi positif dari e-learning. Salah satunya dapat meningkatkan literasi teknologi informasi dan komunikasi bagi guru dan siswa. Hal ini juga dapat dilaksanakan kapan saja tanpa batasan jarak, ruang, dan waktu, serta mengurangi intensitas pertemuan tatap muka sesuai dengan rekomendasi pemerintah. Namun, ada juga kekurangan dari pembelajaran online, salah satunya adalah menurunnya performa individu saat diminta bekerja dalam kelompok. Bekerja dalam kelompok dapat meningkatkan berbagai keterampilan, antara lain kolaborasi, komunikasi, berpikir kritis, dan kreativitas. Keempat keterampilan tersebut dikenal dengan 4C, yaitu keterampilan yang perlu dikuasai oleh siswa pada abad ke-21. Sehingga banyak guru / pendidik yang memilih tugas berkelompok sebagai sarana untuk meningkatkan keterampilan 4C tersebut. Padahal, selama pandemi ini, mahasiswa tidak bisa bertemu secara riil. Rapat hanya dapat dilakukan secara virtual, hal ini dapat mengurangi esensi dari kerja kelompok, dimana prestasi siswa dapat menurun karena membuang tanggung jawab dan merasa tidak perlu mengambilnya sebagai bagian dari tugas. Ini dikenal sebagai kemalasan sosial atau social loafing. Latané, Williams, \& Harkins, (1979) menciptakan 
istilah ini. Social loafing adalah kemalasan sosial, yaitu penurunan kinerja seseorang dalam bekerja sebagai kelompok dibandingkan ketika bekerja secara individu.

Social loafing adalah istilah yang mendefinisikan penurunan kinerja seseorang karena kehadiran orang lain (Harkins, 1987). Istilah ini dibentuk setelah mereplikasi penelitian oleh Ringelmann. Pada percobaan pertama, partisipan diminta bersuara dengan cara bertepuk tangan. Peneliti mengukur upaya partisipan bertepuk tangan sendiri, dengan pasangan, dan dalam kelompok. Pada percobaan kedua, peserta disuruh bersuara dengan berteriak; Prosedurnya sama dengan percobaan pertama, hanya pada percobaan kedua peserta tidak bisa melihat peserta lain. Hasil dari kedua percobaan tersebut menunjukkan bahwa terdapat penurunan suara yang dihasilkan partisipan saat berada dalam kelompok dibandingkan saat partisipan melakukannya sendiri, padahal partisipan tidak bisa melihat partisipan yang lain. Hal ini mengindikasikan bahwa usaha perorangan akan menurun dengan bertambahnya anggota kelompok.

Penurunan usaha itu sendiri dapat disebabkan oleh motivasi individu yang menurun (Hoon \& Tan, 2008). Kemalasan sosial/social loafing adalah kecenderungan individu untuk mengurangi motivasi dan usahanya ketika bekerja dalam kelompok atau secara kolektif dibandingkan ketika bekerja sendiri. Mereka menurunkan usahanya, percaya bahwa tugas itu juga dilakukan oleh orang lain. Alnuaimi, Robert, \& Maruping (2010) mengidentifikasi social loafing sebagai masalah yang disebabkan oleh kurangnya kontrol dan koordinasi dalam kelompok. Social loafing juga digambarkan sebagai kebiasaan seseorang dalam berperilaku malas atau bergantung pada orang lain, yang cenderung terjadi saat bekerja dalam tim (Ying et al., 2014). Ying et al., (2014) membuat alat ukur Social Loafing Tendency Questionnaire, yang digunakan untuk menguji kecenderungan seseorang melakukan social loafing pada tugas individu dan tugas kelompok. Hasil penelitian Ying menunjukkan bahwa kinerja individu dengan kecenderungan social loafing tinggi akan lebih buruk dibandingkan individu dengan kecenderungan social loafing rendah saat mengerjakan tugas kelompok dibandingkan saat bekerja secara individu.

Berdasarkan uraian di atas, dapat dikatakan bahwa social loafing adalah kecenderungan seseorang untuk mengurangi usahanya saat mengerjakan tugas dalam tim dibandingkan saat bekerja secara individu. Dalam beberapa penelitian sebelumnya yang dilakukan oleh Shih \& Wang (2016), terdapat korelasi negatif antara social loafing dengan masalah pertemanan. Artinya, semakin banyak siswa yang kurang bersahabat dengan temannya di kelas maka akan semakin tinggi social loafing. Studi lain oleh Murphy, Wayne, Liden, \& Erdogan (2003) menunjukkan pertukaran antarpribadi (seperti siswa yang brilian versus siswa yang kurang cemerlang) memainkan peran dan mempengaruhi proses kemalasan sosial. Temuan paling terkait dengan penelitian ini dilakukan oleh Kidwell (2010) tentang cyber-loafing di abad ke-21. Berdasarkan hasil penelitian, terdapat beberapa masalah yang ditemukan selama bekerja di lingkungan kerja virtual, antara lain kurangnya tenaga kerja kelompok secara virtual, lebih banyak menghabiskan waktu di internet untuk aktivitas non-kerja, dll.

Aspek esensial yang harus diperhatikan oleh calon guru (mahasiswa Pendidikan Guru Sekolah Dasar) dalam melaksanakan pembelajaran IPA di sekolah dasar adalah melibatkan siswa dalam pembelajaran untuk mengembangkan kemampuan berpikirnya secara aktif. Pembelajaran IPA dimulai dengan memperhatikan konsepsi/ pengetahuan awal siswa yang relevan dengan apa yang dipelajari. Selanjutnya kegiatan belajar dirancang melalui berbagai kegiatan nyata dengan alam. Kegiatan pengalaman dengan alam dapat dilakukan di ruang kelas atau laboratorium dengan alat bantu belajar atau dilakukan langsung di tempat terbuka. Melalui kegiatan nyata dengan alam, siswa dapat mengembangkan keterampilan dan sikap proses ilmiah seperti mengamati, bereksperimen, menyimpulkan hasil kegiatan, dan mengkomunikasikannya (Baharun \& Adhimiy, 2018; Saputra, Al Auwal, \& Mustika, 2017). Kegiatan pembelajaran IPA juga dirancang untuk memberikan kesempatan kepada siswa untuk bertanya. Dengan bertanya, anak akan berlatih mengungkapkan gagasan dan tanggapan atas masalah yang dihadapinya sehingga dapat mengembangkan pengetahuan ilmiahnya. Selain mengajukan pertanyaan, siswa juga diperbolehkan menjelaskan suatu masalah berdasarkan pemikirannya.

Berdasarkan uraian di atas, pembelajaran IPA yang dilaksanakan dengan mengangkat permasalahan dunia nyata yang dialami anak akan lebih diminati oleh anak sehingga mereka terlibat aktif dalam mengembangkan kemampuan berpikirnya. Ini sangat terkait dengan keterampilan guru. Jika guru terbiasa melakukan kerja tim, mereka akan dapat menguraikan potensi masing-masing individu dalam kolaborasi. Itulah mengapa bekerja dalam kelompok sangat penting dalam pendidikan guru SD. Beberapa manfaat bekerja sebagai kerja tim adalah, 1) mengembangkan keterampilan berpikir tingkat tinggi; 2) meningkatkan interaksi yang lebih akrab antara calon guru dan siswanya; 3) membangun kepercayaan diri; 4) meningkatkan tingkat kepuasan calon guru karena peningkatan pengalaman; 5) meningkatkan sikap positif terhadap materi pelajaran; 6) mengembangkan keterampilan lisan, keterampilan berbicara; 7) mengembangkan keterampilan interaksi sosial; 8) menciptakan suasana pembelajaran aktif yang penuh keterlibatan dan eksplorasi oleh calon guru (Effendi, 2018; Erni Ivianti, 2017). 
Penelitian ini bertujuan untuk mengetahui apakah ada pengaruh pemberian tugas kelompok yang dilakukan secara daring terhadap social loafing mahasiswa Pendidikan Guru Sekolah Dasar dan bagaimana solusi yang paling sesuai.

\section{B. METODE PENELITIAN}

Penelitian ini merupakan penelitian kualitatif. Subjek dalam penelitian ini adalah mahasiswa Pendidikan Guru Sekolah Dasar pada mata kuliah IPA angkatan 2019. Pengumpulan data dilakukan dengan survei dan observasi online selama tiga bulan pembelajaran online. Seorang mahasiswa sebagai penanggung jawab ditunjuk untuk memastikan survei dikumpulkan secara keseluruhan dan jujur. Total ada 55 survey yang dikirim, dan 39 di antaranya sudah direspon dengan valid. Analisis data menggunakan statistik deskriptif dan studi pustaka.

\section{HASIL DAN PEMBAHASAN}

Survei dilakukan secara online melalui Google Form. Pertanyaan-pertanyaan tersebut dimodifikasi dari Social Loafing Tendencies Questionnaire (SLTQ) (Ying et al. 2014). Berikut adalah data dan analisis proses social loafing.

\section{Profil Partisipan}

Partisipan dalam penelitian ini terdiri dari 7 mahasiswa laki-laki $(17,94 \%)$ dan 32 perempuan $(82,06 \%)$ pada mata pelajaran IPA kelas Konsep Dasar Fisika SD, dengan latar belakang pendidikan yang sama yaitu SMA. Ada 29 mahasiswa berusia 18 tahun (74,36\%), 4 berusia 19 tahun (10,25\%), dan 6 berusia 20 tahun $(15,38 \%) .30$ orang diantaranya tinggal di Surabaya, Indonesia (76.92\%), dan 9 orang diantaranya tinggal di luar Surabaya (23.08\%).

2. Partisipasi dalam Pembelajaran Online

Partisipasi dalam pembelajaran online yang dibahas adalah apakah mahasiswa mengikuti semua perkuliahan online secara penuh, apakah mereka dapat memahami materi dari kelas online, dan persentase pemahaman mata kuliah online yang diikuti.
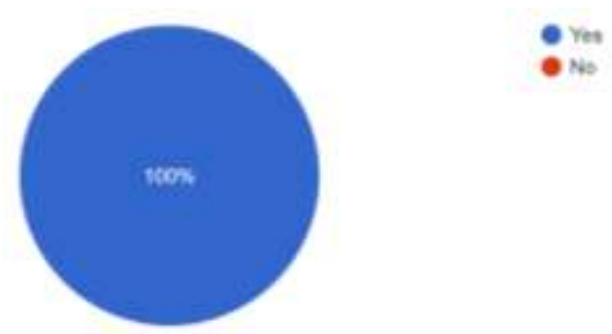

Gambar 1. Partisipasi Mahasiswa dalam Pembelajaran Daring
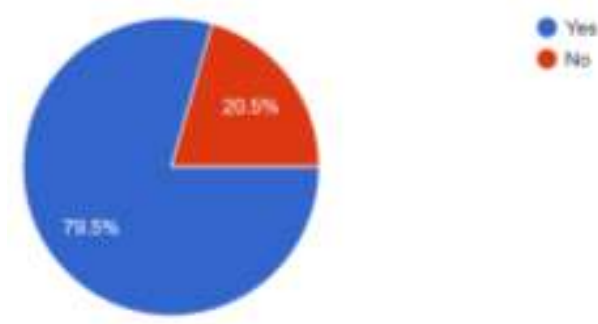

Gambar 2. Pemahaman Materi Mahasiswa dalam Pembelajaran Daring

Gambar di atas menunjukkan bahwa mahasiswa mengikuti semua kelas online (100\%) dan kurang memahami kelas online (20,50\% tidak memahami materi yang diberikan dalam pembelajaran online). Ada beberapa alasan mengapa mereka tidak memahami lebih baik dengan pembelajaran online, pertama karena mereka belajar sendiri; kedua, mereka belajar tanpa penjelasan dosen, dan ketiga, mereka tidak bisa berdiskusi dengan sesama. Tingkat pemahaman berdasarkan lima indikator adalah sebagai berikut; 5 sangat baik ( 3 mahasiswa), 4 sangat baik (19 mahasiswa), 3 baik (15 mahasiswa), cukup baik ( 2 mahasiswa). 


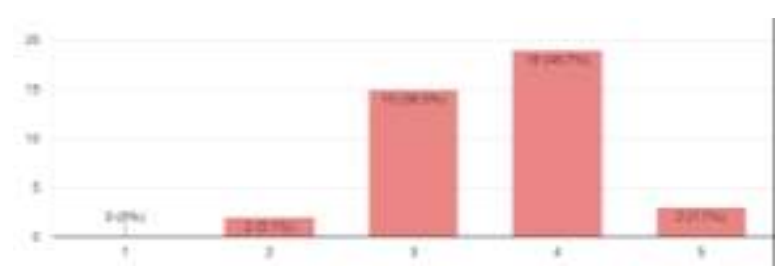

Gambar 3. Tingkat Pemahaman Mahasiswa dalam Materi yang Diberikan

Indikator pemahaman dalam perkuliahan adalah: 1) mendeskripsikan pengertian getaran; 2) menganalisis konsep-konsep yang berbeda tentang periode, frekuensi, dan amplitudo getaran; 3) menginterpretasikan gelombang dan propertinya; 4) mendeskripsikan jenis gelombang; 5) membedakan fenomena dan contoh gelombang mekanis. Ini adalah mata pelajaran pada mata kuliah IPA Mata Kuliah Konsep Dasar Fisika SD. Universitas menyediakan platform yang digunakan untuk proses pembelajaran sains. Berbagai fasilitas yang dimiliki antara lain file sharing, forum diskusi, evaluasi, dll. Meski banyak kelebihan yang bisa digunakan dalam platform ini, baik dosen maupun guru pendamping tidak dapat memaksimalkan fasilitas yang disediakan. Selain itu, para guru tidak mampu melakukan praktek dalam situasi nyata seperti laboratorium virtual yang sangat dibutuhkan oleh mata kuliah IPA. Selain laboratorium virtual, bekerja dalam kelompok dapat meningkatkan lebih banyak keterampilan mahasiswa sains (Izzatunnisa, Andayani, \& Hakim, 2019; Saputra et al., 2017). Hal ini tentunya juga menjadi faktor penentu keberhasilan pembelajaran online. Alasan lainnya, jika mahasiswa sudah mengenal pembelajaran sistem online maka modal esensial dalam proses pembelajaran sistem online dapat terpenuhi. Mengingat teknik dasar seperti mengoperasikan aplikasi penting untuk menunjang keberhasilan pembelajaran dengan sistem online ini.

3. Kontribusi Mahasiswa selama Kerja Kelompok

Aspek kontribusi dalam penelitian ini adalah: 1) apakah mereka berkontribusi dan memberi dukungan dalam kelompok; 2) apakah mereka menyumbangkan gagasan dan perhatian mereka dalam kelompok; 3) apakah mereka menyelesaikan bagian mereka dalam grup. Dan jawabannya ditunjukkan pada Gambar 4, 5, 6 di bawah ini.

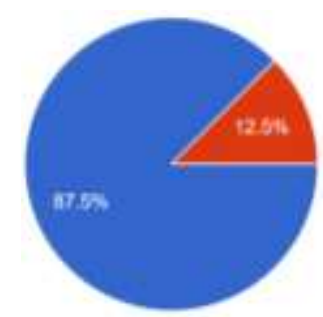

Gambar 4. Respon Mahasiswa terhadap Pertanyaan Memberi Kontribusi dalam Kerja Kelompok

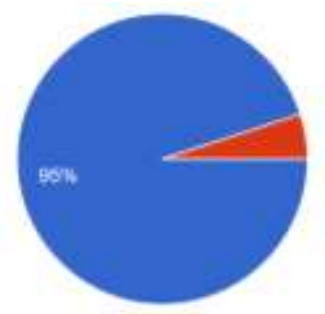

Gambar 5. Respon Mahasiswa terhadap Pertanyaan Memberi Ide dalam Kelompok

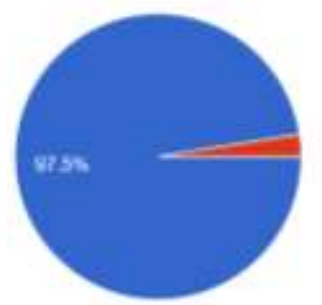

Gambar 6. Respon Mahasiswa tentang Menyelesaikan Bagian Mereka dalam Kerja Kelompok selama Pembelajaran Online 
Hasil pada Gambar 4, 12,50\% mahasiswa memilih ya tentang tidak memberikan kontribusi pada kerja tim dibandingkan dengan pertemuan offline. Hal ini sesuai dengan penelitian sebelumnya oleh Shih dan Wang (2016) bahwa terdapat hubungan negatif antara persahabatan dalam kerjasama tim dan sosial bermalas-malasan. Jika setiap mahasiswa saling mengenal dengan baik, dan mereka menyadari bagian mereka dalam kelompok, mereka akan berusaha lebih keras untuk melakukan tugas dengan lebih baik. Saat offline, supervisor (dalam hal ini dosen) bisa mengawasi pekerjaannya. Di sisi lain, ketika belajar online, supervisor tidak dapat memastikan mana yang lebih baik dan mana yang kurang. Gambar 5 menunjukkan bahwa 95\% sebagian besar kelas menyumbangkan idenya untuk kerja kelompok. Ying et al. (2014) menemukan konseptualisasi kecenderungan bermalas malas sosial sebagai respon kebiasaan. Artinya bagi individu dengan kecenderungan social loafing yang tinggi, pengaturan kelompok akan mengaktifkan kecenderungan ini, yang berujung pada menghasilkan efek negatif pada kinerja kelompok. Tetapi pada individu yang memiliki kecenderungan sosial yang kurang, tidak akan ada efek negatif pada kinerja kelompok. Pertanyaan pada Gambar 6 menghasilkan 97,50\% guru prajabatan menyelesaikan bagian mereka dalam kerja tim. 2,50\% lainnya tidak menyelesaikan pekerjaannya. Hal tersebut disebabkan oleh banyak hal, menurut wawancara singkat dengan mereka, alasan yang paling dapat diterima adalah kurangnya kuota internet. Selain itu, pemahaman mereka tentang mata kuliah (Gambar 3) juga berdampak pada kinerja mereka dalam tugas kelompok.

4. Preferensi Mahasiswa pada Kerja Kelompok berbasis Online

Preferensi dalam penelitian ini berarti apakah mahasiswa semakin malas atau lebih bersemangat melakukan kerja kelompok dan preferensi mereka untuk menyelesaikan tugas secara individu atau kelompok.
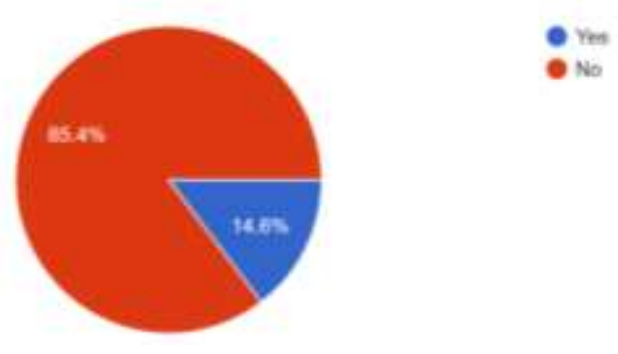

Gambar 7. Respon Mahasiswa tentang Menjadi Malas dalam Pekerjaan Kelompok

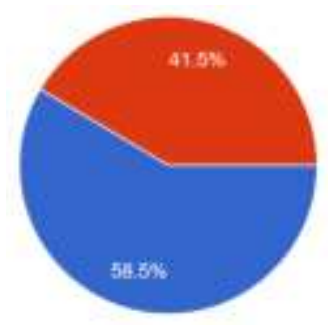

Working in prow

Gambar 8. Preferensi Mahasiswa terhadap Tugas yang Diberikan

Hasil pada gambar di atas $14,60 \%$ dari mereka memilih ya karena semakin malas dalam kerja kelompok, $58,50 \%$ dari mereka memilih bekerja secara individu lebih baik daripada bekerja dalam kelompok. Analisis data di atas sesuai dengan penelitian yang dilakukan oleh Kidwell (2010). Masalah dalam kerja tim virtual adalah individu-individu menurunkan tingkat usaha mereka karena sulit bagi dosen untuk mengamati dan mengidentifikasi dampak upaya individu terhadap kinerja tim. Pemulihannya bisa dengan memberi seseorang dalam kelompok tanggung jawab untuk menjadi orang yang bertanggung jawab, memastikan ada akuntabilitas timbal balik untuk mencapai tujuan tim, dan fokus untuk mencapainya. Selain itu, harus ada reward yang diberikan kepada beberapa anggota tim yang lebih banyak berperan dalam kerja kelompok.

Solusi terbaru yang diusulkan oleh Shih dan Wang (2016) untuk meningkatkan kinerja kelompok, harus ada hubungan persahabatan yang kuat dan baik antara anggota kelompok.

\section{SIMPULAN DAN SARAN}

Tujuan utama penelitian ini adalah untuk mengetahui apakah terdapat indikasi perilaku social loafing dalam kerja kelompok selama pembelajaran daring di periode pandemi Covid-19 ini. Hasilnya menunjukkan bahwa ada sedikit gejala social loafing, yang dapat menyebabkan efek negatif pada penyelesaian tugas dan stres dan ketegangan individu. Hal tersebut harus diselesaikan secepatnya, mengingat subjek adalah calon guru SD (mahasiswa Pendidikan Guru Sekolah Dasar), yang harus memberikan teladan yang sangat baik kepada 
siswanya di masa depan. Solusi yang diusulkan dalam penelitian ini adalah memberikan tanggung jawab kepada seseorang di setiap kelompok untuk memastikan semua anggota tim melakukan bagian mereka dalam kerja kelompok, menjaga saling membantu di antara mereka, dan meminimalkan kemungkinan terjadinya social loafing.

Saran untuk penelitian selanjutnya adalah membahas seberapa jauh dampak social loafing pada individu dalam kehidupan di jenjang karier professional, apakah ada pengaruh dari masa kuliahnya. Hal ini penting untuk diketahui dalam jangka panjang agar efek yang diberikan tidak berakibat fatal.

\section{DAFTAR RUJUKAN}

[1] Alnuaimi, O. A., Robert, L. P., \& Maruping, L. M. 2010. Team size, dispersion, and social loafing in technology-supported teams: A perspective on the theory of moral disengagement. Journal of Management Information Systems, 27(1), 203-230.

[2] Baharun, H., \& Adhimiy, S. 2018. Curriculum Development Through Creative Lesson Plan. Cendekia: Jurnal Kependidikan Dan Kemasyarakatan, 16(1), 41-62.

[3] Effendi, M. 2018. Pembelajaran berbasis proyek (PjBL) untuk mengembangkan kemampuan berpikir kritis mahasiswa PGMI IAIN Ponorogo. Cendekia: Jurnal Kependidikan Dan Kemasyarakatan, 15(2), 305-318.

[4] Erni Ivianti, S. 2017. Meningkatkan Hasil Belajar Siswa dengan Menggunakan Metode Project Based Learning. Jurnal Handayani, 7, 92-99. https://doi.org/10.24114/jh.v7i2.7239

[5] Harkins, S. G. 1987. Social loafing and social facilitation. Journal of Experimental Social Psychology, 23(1), 1-18.

[6] Hoon, H., \& Tan, T. M. L. 2008. Organizational citizenship behavior and social loafing: The role of personality, motives, and contextual factors. The Journal of Psychology, 142(1), 89-108.

[7] Izzatunnisa, I., Andayani, Y., \& Hakim, A. 2019. Pengembangan LKPD berbasis pembelajaran penemuan untuk meningkatkan kemampuan literasi sains peserta didik pada materi kimia SMA. Jurnal Pijar Mipa, 14(2), 49-54.

[8] Khasanah, D. R. A. U., Pramudibyanto, H., \& Widuroyekti, B. 2020. Pendidikan Dalam Masa Pandemi Covid-19. Jurnal Sinestesia, 10(1), 41-48.

[9] Kidwell, R. E. 2010. Loafing in the 21st century: Enhanced opportunities-and remedies-for withholding job effort in the new workplace. Business Horizons, 53(6), 543-552.

[10] Latané, B., Williams, K., \& Harkins, S. 1979. Many hands make light the work: The causes and consequences of social loafing. Journal of Personality and Social Psychology, 37(6), 822.

[11] Murphy, S. M., Wayne, S. J., Liden, R. C., \& Erdogan, B. 2003. Understanding social loafing: The role of justice perceptions and exchange relationships. Human Relations, 56(1), 61-84.

[12] Saputra, H., Al Auwal, T. M. R., \& Mustika, D. 2017. Pembelajaran inkuiri berbasis virtual laboratory untuk meningkatkan kemampuan literasi sains mahasiswa calon guru pendidikan fisika Universitas Samudra. JIPI (Jurnal IPA \& Pembelajaran IPA), 1(2), 143-148.

[13] Shih, C.-H., \& Wang, Y.-H. 2016. Can workplace friendship reduce social loafing? 2016 10th International Conference on Innovative Mobile and Internet Services in Ubiquitous Computing (IMIS), 522-526. IEEE.

[14] Ying, X., Li, H., Jiang, S., Peng, F., \& Lin, Z. 2014. Group laziness: The effect of social loafing on group performance. Social Behavior and Personality: An International Journal, 42(3), 465-471. 